\title{
Recent advances in the management of post-operative intracerebral vasospasm
}

\author{
Harihar Dash
}

\section{Abstract}

\begin{abstract}
Postoperative intracerebral vasospasm is one of the leading causes of morbidity and mortality following clipping of intra cranial aneurysm. Early diagnosis, prompt and effective management helps in salvaging these patients. Umpteen modalities of treatment strategies are available to achieve good neurologic recovery. Intraarterial nimodipine, nicardipine and milrinon provide good neurologic recovery. Stellate ganglion block on the affected side is also a treatment modality which needs to be investigated.
\end{abstract}

Key words: Aneurysmal, intracerebral, vasospasm

\section{INTRODUCTION}

Symptomatic vasospasm, commonly known as delayed ischaemic neurological deficit, is one of the most common complications after aneurysmal clipping and is the leading cause of death in patients who survive the rupture. Vasospasm-induced narrowing of cerebral vessels is estimated to occur in $70 \%$ of patients hospitalised for subarachnoid haemorrhage (SAH). ${ }^{[1]}$ Vasospasm is symptomatic in $46 \%$ of these patients. In survivors, it is the major cause of disability, with a $25 \%$ decrease in excellent outcome. ${ }^{[2,3]}$ Despite better understanding of the pathophysiology of vasospasm, its management still remains a great challenge.

\section{CLINICAL PRESENTATION}

The onset of new or worsening neurological signs or symptoms in the absence of dyselectrolytemia,

Department of Anaesthesiology and Pain Medicine, Fortis Memorial Research Institute, Gurgaon, Haryana, India

Address for correspondence:

Dr. Harihar Dash, Department of Anaesthesiology and Pain Medicine, Fortis Memorial Research Institute, Gurgaon, Haryana, India.

E-mail: dr.harihardash@gmail.com

\begin{tabular}{|l|l|}
\hline \multicolumn{2}{|c|}{ Access this article online } \\
\hline Quick Response Code: & Website: \\
\hline & www.jnaccjournal.org \\
\cline { 2 - 2 } & \\
\hline & DOI: \\
\hline
\end{tabular}

hydrocephalus or any intracranial haematoma is the most reliable indicator of vasospasm that classically starts around $3^{\text {rd }}$ day post-ictus and may last up to 14 days. Intermittent disorientation, which can progress to focal neurological deficits such as hemiparesis and speech dysfunction, can manifest as a predominant clinical feature of intracerebral vasospasm. If untreated, it may result in permanent disability and even death.

\section{PATHOPHYSIOLOGY}

The aetiology and pathophysiology of cerebral vasospasm after SAH is complex. Oxyhaemoglobin plays a primary role in the development of cerebral vasospasm associated with aneurysmal SAH. Erythrocytes trapped in the subarachnoid cisterns slowly haemolyse, releasing oxyhaemoglobin and other by-products of red cell lysis (e.g., bilirubin and methaemoglobin) to circulate within the subarachnoid space. These spasminogens increase the influx of calcium into the vascular smooth muscle, altering myocyte function and causing prolonged contraction and vessel constriction. Oxyhaemoglobin also contributes to release of free radicals and peroxidation of lipids. These changes

This is an open access article distributed under the terms of the Creative Commons Attribution-NonCommercial-ShareAlike 3.0 License, which allows others to remix, tweak, and build upon the work non-commercially, as long as the author is credited and the new creations are licensed under the identical terms.

For reprints contact: reprints@medknow.com

How to cite this article: Dash $\mathrm{H}$. Recent advances in the management of post-operative intracerebral vasospasm. J Neuroanaesthesiol Crit Care 2017;4:S56-9. 
promote the synthesis of vasoactive eicosanoids and endothelin and inhibit endothelium-dependent relaxation of the arterial wall, resulting in arterial spasm.

\section{DIAGNOSIS}

Various modalities available for diagnosis of intracerebral vasospasm are clinical, transcranial Doppler (TCD) and intracerebral angiography. TCD is a non-invasive method for monitoring cerebral vasospasm. Elevated flow velocities of the middle cerebral artery (MCA) on TCD $>120 \mathrm{~cm} / \mathrm{s}$ correlate well with angiographic narrowing of cerebral vessels. Mean flow velocity of the MCA of $200 \mathrm{~cm} / \mathrm{s}$ or greater indicates severe cerebral vasospasm and correlate with $>50 \%$ or greater narrowing of cerebral vessels on cerebral angiography.

\section{LINDEGAARD RATIO}

Lindegaard ratio is the ratio of mean blood flow velocity of the MCA to ipsilateral internal carotid artery flow velocity which did not improve the predictive value of TCD monitoring. Normal ratio is 3.0. Ratio of 3.1-5.9 suggests moderate-to-severe vasospasm and more than 6.0 suggests severe vasospasm. However, it is operator dependent, and multiple systemic factors can alter flow velocities.

\section{MANAGEMENT}

Clipping the aneurysm or using an endovascular intervention (e.g., coiling, stenting or angioplasty) within $48 \mathrm{~h}$ of the initial haemorrhage is imperative to minimise the occurrence and aggravation of both vasospasm and rebleeding. In addition, early surgical clot removal limits the amount of oxyhaemoglobin released, reducing the incidence of vasospasm. Administration of calcium channel blockers and use of triple $\mathrm{H}$ therapy are both widely accepted interventions after clipping or coiling to treat vasospasm.

\section{GENERAL CARE}

Assessment of airway, breathing and taking care of the circulatory status of the patient is of paramount importance. To maintain the blood pressure of the patient, intravenous infusion of normal saline is usually preferred. If the patient is diabetic, the blood sugar control is imperative and sliding scale management is ideal.

\section{NIMODIPINE}

A calcium channel blocker decreases spasm in the cerebral vascular bed and can lead to improvement in long-term outcomes after SAH. Patients are prophylactically given oral nimodipine at a dosage of $60 \mathrm{mg}$, for every $4 \mathrm{~h}$, for 21 days following SAH. The calcium antagonist nimodipine has been shown to reduce the incidence of ischaemic complications following SAH ${ }^{[4]}$ Although most randomised studies have focused on the effect of the oral administration of nimodipine, intravenous infusion is an alternative and the preferred mode of treatment in many centres. A recent clinical trial carried out on 106 patients with acute aneurysmal SAH was randomised to receive either peroral or intravenous nimodipine treatment. There was no significant difference in the incidence of delayed ischaemic neurologic deficits (DINDs) or MCA blood flow velocities. Clinical outcome according to the Glasgow Outcome Scale (GOS) was the same in both groups. Both routes can be used safely for administering nimodipine to treat intracerebral vasospasm following SAH. ${ }^{[5]}$

\section{TRIPLE H THERAPY}

The three components of triple $\mathrm{H}$ therapy are hypertension, hypervolaemia and haemodilution. Importantly, these interventions affect the symptoms of vasospasm rather than the underlying cause. ${ }^{[6]} \mathrm{A}$ hypertensive state is maintained through the use of vasopressors ( $20 \%-30 \%$ of the basal value of systolic blood pressure). Hypervolaemia is obtained by using volume expansion, which subsequently produces haemodilution. These manoeuvres are all designed to increase cerebral perfusion pressure, improve blood flow to the brain and decrease the risk of ischaemia. Importantly, despite the apparent reversal of neurological deficits, no evidence indicates that morbidity or mortality is reduced after triple $\mathrm{H}$ therapy. The complications include pulmonary oedema, myocardial ischaemia, congestive heart failure, electrolyte imbalances, coagulopathies and rupture of unsecured aneurysms. Costs associated with triple $\mathrm{H}$ therapy are substantial and are related to additional nursing care requirements, extended critical care unit lengths of stay, aggressive fluid management, frequent complications and expenses associated with placement and monitoring of pulmonary artery catheters. ${ }^{[6,7]}$

\section{ANGIOPLASTY}

Balloon angioplasty directly treats narrowed cerebral vessels by widening the stenotic segment. The balloon causes functional impairment of smooth muscle in the vessel wall, reducing or eliminating further vasospasm. An important limitation of balloon angioplasty is that it can be used to widen only larger vessels. The most devastating complication associated with angioplasty is vessel rupture.

\section{PAPAVERINE}

Selective intra-arterial (IA) injection of papaverine directly into spastic vessels can reverse the spasm. The main advantage of papaverine is that it can be used 
to treat distal vessels, those beyond the reach of an angioplasty balloon. Use of this agent is controversial; significant increases in intracranial pressure and disruption of the blood brain-barrier ${ }^{[8]}$ can occur after instillation. Recurrence of spasm is another major concern. Intrathecal papaverine has also been used to treat vasospasm by some researchers.

\section{EFFECTS OF INTRA-ARTERIAL NICARDIPINE INFUSION}

Intra-arterial nicardipine infusion on the cerebral haemodynamics of patients with clinical and TCD findings suggestive of vasospasm was evaluated by computed tomography (CT) angiography and quantitative cine CT perfusion (CTP). In five of the six patients, both cerebral blood flow (CBF) and maps of mean transit time (MTT) improved significantly. The authors have concluded that IA nicardipine improves CBF and MTT in ischaemic regions in patients with SAH-induced vasospasm, and cine CTP may provide a surrogate marker for monitoring the success of treatment strategies in patients with $\mathrm{SAH}$-induced vasospasm. ${ }^{[9]}$

\section{MAGNESIUM}

Magnesium, a physiological calcium antagonist, has shown comparable efficacy to nimodipine in preventing neurological deficits. ${ }^{[10]}$ Large multicentric trial is going on and the results are awaited.

\section{STATINS}

Statins have shown to decrease the level of markers of brain injury and decrease the incidence of vasospasm and neurological deficit. Among the statins, simvastatin has been observed to be more useful. ${ }^{[11]}$

\section{MILRINONE}

Milrinone, a phosphodiesterase III inhibitor and an inodilator, has been used both intravenously and intraarterially to treat intracerebral vasospasm following aneurysmal SAH. ${ }^{[12]}$ IA milrinone has been found to be more useful. ${ }^{[13,14]}$ Intracisternal milrinone has been used experimentally to treat intracerebral vasospasm in dogs with a good result.

\section{SYMPATHETIC GANGLION BLOCKADE}

Cervical sympathetic block has shown to improve cerebral perfusion in aneurysmal SAH. ${ }^{[15]}$ Stellate ganglion block has shown to improve cerebral perfusion pressure in healthy individuals. ${ }^{[16]}$ In two patients, with refractory cerebral vasospasm, stellate ganglion block significantly improved the clinical condition as well as cerebral haemodynamics. ${ }^{[17]} \mathrm{A}$ trial is currently being conducted for its efficacy in patients with aneurysmal SAH. ${ }^{[18]}$

\section{CERVICAL SPINAL CORD STIMULATION}

Cervical spinal cord stimulation (SCS) increases global cerebral blood flow (CBF) and ameliorates cerebral ischaemia according to a number of experimental models as well as some anecdotal reports in humans. A recent study carried out on rats with SAH has shown that SCS can reverse basilar artery combination and improve global CBF. ${ }^{[19]}$ Let us wait for human trials.

\section{EFFECT OF $\mathrm{N}_{2} \mathrm{O}$ ON INTRACEREBRAL VASOSPASM}

Laboratory studies suggest that $\mathrm{N}_{2} \mathrm{O}$ augments brain injury after ischaemia or hypoxia. ${ }^{[20]}$ Recently, the Intraoperative Hypothermia for Aneurysm Surgery Trial study group has examined the relation between $\mathrm{N}_{2} \mathrm{O}$ and outcomes of patients after aneurysm surgery. Out of 1000 patients, 373 patients received $\mathrm{N}_{2} \mathrm{O}$. There was no difference between groups in the development of DIND. At 3 months after surgery, there were no significant differences between groups in any outcome variable (GOS, NIH stroke scale, Rankin disability score, Barthel activities and neuropsychological testing). The authors have concluded that in a population of patients at risk of ischaemic brain injury, $\mathrm{N}_{2} \mathrm{O}$ use had no overall beneficial or detrimental impact on neurologic or neuropsychological outcomes. ${ }^{[21]}$

\section{GENE AND STEM CELL THERAPY}

Continuing research in gene and stem cell therapy may unravel the management strategies of intracerebral vasospasm in the foreseeable future.

\section{CONCLUSION}

Though a plethora of treatment modalities are available to manage intracerebral vasospasm, none has been found to be very useful. Still the search for a magic bullet continues.

\section{Financial support and sponsorship} Nil.

\section{Conflicts of interest}

There are no conflicts of interest.

\section{REFERENCES}

1. Suarez JI, Tarr RW, Selman WR. Aneurysmal subarachnoid hemorrhage. N Engl J Med 2006;354:387-96.

2. Buchanan KM, Elias LJ, Goplen GB. Differing perspectives on 
outcome after subarachnoid hemorrhage: The patient, the relative, the neurosurgeon. Neurosurgery 2000;46:831-8.

3. Rabinstein AA, Friedman JA, Weigand SD, McClelland RL, Fulgham JR, Manno EM, et al. Predictors of cerebral infarction in aneurysmal subarachnoid hemorrhage. Stroke 2004;35:1862-6.

4. Pickard JD, Murray GD, Illingworth R, Shaw MD, Teasdale GM, Foy PM, et al. Effect of oral nimodipine on cerebral infarction and outcome after subarachnoid haemorrhage: British aneurysm nimodipine trial. BMJ 1989;298:636-42.

5. Kronvall E, Undrén P, Romner B, Säveland $\mathrm{H}$, Cronqvist $\mathrm{M}$, Nilsson OG. Nimodipine in aneurysmal subarachnoid hemorrhage: A randomized study of intravenous or peroral administration. J Neurosurg 2009;110:58-63.

6. Romner B, Reinstrup P. Triple $\mathrm{H}$ therapy after aneurysmal subarachnoid hemorrhage. A review. Acta Neurochir Suppl 2001;77:237-41.

7. Corsten L, Raja A, Guppy K, Roitberg B, Misra M, Alp MS, et al. Contemporary management of subarachnoid hemorrhage and vasospasm: The UIC experience. Surg Neurol 2001;56:140-8.

8. Platz J, Baráth K, Keller E, Valavanis A. Disruption of the blood-brain barrier by intra-arterial administration of papaverine: A technical note. Neuroradiology 2008;50:1035-9.

9. Nogueira RG, Lev MH, Roccatagliata L, Hirsch JA, Gonzalez RG, Ogilvy CS, et al. Intra-arterial nicardipine infusion improves CT perfusion-measured cerebral blood flow in patients with subarachnoid hemorrhage-induced vasospasm. AJNR Am J Neuroradiol 2009;30:160-4.

10. Schmid-Elsaesser R, Kunz M, Zausinger S, Prueckner S, Briegel J, Steiger HJ. Intravenous magnesium versus nimodipine in the treatment of patients with aneurysmal subarachnoid hemorrhage: A randomized study. Neurosurgery 2006;58:1054-65.

11. Lynch JR, Wang H, McGirt MJ, Floyd J, Friedman AH, Coon AL, et al. Simvastatin reduces vasospasm after aneurysmal subarachnoid hemorrhage: Results of a pilot randomized clinical trial. Stroke 2005;36:2024-6.
12. Fraticelli AT, Cholley BP, Losser MR, Saint Maurice JP, Payen D. Milrinone for the treatment of cerebral vasospasm after aneurysmal subarachnoid hemorrhage. Stroke 2008;39:893-8

13. Bouchard M, Verreault S, Gariépy JL, Dupré N. Intra-arterial milrinone for reversible cerebral vasoconstriction syndrome. Headache 2009;49:142-5.

14. Schmidt U, Bittner E, Pivi S, Marota JJ. Hemodynamic management and outcome of patients treated for cerebral vasospasm with intraarterial nicardipine and/or milrinone. Anesth Analg 2010;110:895-902.

15. Treggiari MM, Romand JA, Martin JB, Reverdin A, Rüfenacht DA de Tribolet $N$. Cervical sympathetic block to reverse delayed ischemic neurological deficits after aneurysmal subarachnoid hemorrhage. Stroke 2003;34:961-7.

16. Gupta MM, Bithal PK, Dash HH, Chaturvedi A, Mahajan RP. Effects of stellate ganglion block on cerebral haemodynamics as assessed by transcranial Doppler ultrasonography. $\mathrm{Br} \mathrm{J}$ Anaesth 2005;95:669-73.

17. Prabhakar H, Jain V, Rath GP, Bithal PK, Dash HH. Stellate ganglion block as alternative to intrathecal papaverine in relieving vasospasm due to subarachnoid hemorrhage. Anesth Analg 2007;104:1311-2.

18. Jain V, Rath GP, Dash HH, Bithal PK, Chouhan RS, Suri A. Stellate ganglion block for treatment of cerebral vasospasm in patients with aneurysmal subarachnoid hemorrhage - A preliminary study. J Anaesthesiol Clin Pharmacol 2011;27:516-21.

19. Lee JY, Huang DL, Keep R, Sagher O. Effect of electrical stimulation of the cervical spinal cord on blood flow following subarachnoid hemorrhage. J Neurosurg 2008; 109:1148-54.

20. Culley DJ, Crosby G. Nitrous oxide in neuroanesthesia: Tried and true or toxin? Anesthesiology 2008;108:553-4.

21. McGregor DG, Lanier WL, Pasternak JJ, Rusy DA, Hogan K, Samra S, et al. Effect of nitrous oxide on neurologic and neuropsychological function after intracranial aneurysm surgery. Anesthesiology 2008;108:568-79. 